\title{
ETHNIC MINORITY LANGUAGE CULTURE, PLACES WITH ORIGINAL TAY LANGUAGE ELEMENTS AND NAMES INCONSISTENCE IN TUYEN QUANG PROVINCES
}

\author{
CULTURA DE LÍNGUA ÉTNICA MINORITARIA, LUGARES COM ELEMENTOS \\ ORIGINAIS DA LÍNGUA TAY E INCONSISTENCIA DE NOMES NAS PROVÍNCIAS \\ DE TUYEN QUANG
}

\author{
CULTURA LINGÜÍSTICA DE LAS MINORÍAS ÉTNICAS, LUGARES CON \\ ELEMENTOS ORIGINALES DE LA LENGUA TAY E INCONSISTENCIA DE LOS \\ NOMBRES EN LAS PROVINCIAS DE TUYEN QUANG
}

\author{
Duong THI NGU ${ }^{1}$ \\ Dinh Tran NGOC HUY ${ }^{2}$
}

\begin{abstract}
The article is composed statistically using maps of all types, documents on marital status, family records, and administrative documents (collectively referred to as Vietnamese documents). Place names with elements of Tay origin in Tuyen Quang province based on 4 districts (Chiem Hoa, Lam Binh, Na Hang, and Son Duong) were researched, with the intention of gaining insight into place names with original elements that come from ethnic minority languages in Vietnam, being read and written in different ways. The difference in the phonetics and writing of Tay language compared to Vietnamese, is one of the reasons that place names with elements of Tay origin in Tuyen Quang province, are used inconsistently, resulting in different ways of reading, and writing a place name. Therefore, there is a need to standardize all place names located in the province.
\end{abstract}

KEYWORDS: Place names. Tay language. Phonetic. Tuyen Quang. Vietnamese.

RESUMO: O artigo se compõe estatisticamente através de mapas de todos os tipos, documentos sobre estado civil, registros familiares e documentos administrativos (coletivamente referidos como documentos vietnamitas). Foi pesquisado acerca dos nomes de lugares com elementos de origem Tay na província de Tuyen Quang baseando-se em 4 distritos (Chiem Hoa, Lam Binh, Na Hang, e Son Duong), com a intenção de obter ganhos sobre os nomes de lugares com elementos originais que são advindos de linguas de minorias étnicas no Vietnã, sendo lidos e escritos de diferentes maneiras. A diferença na fonética e na escrita da língua Tay em relação ao vietnamita, é uma das razões que fazem com que nomes de lugares com elementos de origem Tay na província de Tuyen Quang, sejam usados de forma inconsistente, o que resulta em diferentes maneiras de ler e escrever o nome de um lugar. Portanto, há uma necessidade de padronizar todos os nomes dos locais situados na província.

PALAVRAS-CHAVE: Nomes de lugares. Idioma tay. Fonética. Tuyen Quang. Vietnamita.

\footnotetext{
${ }^{1}$ Tan Trao University, Tuyen Quang - Vietnam. ORCID: https://orcid.org/0000-0002-2510-9876. E-mail: duong.thingu@gmail.com

2 Banking University HCMC, Ho Chi Minh - Vietnam, International University of Japan (IUJ), Niigata - Japan. ORCID: https://orcid.org/0000-0002-1782-380X. E-mail: dtnhuy.2010@gmail.com
} 
RESUMEN: El documento se compone estadísticamente a través de mapas de todo tipo, documentos sobre el estado civil, registros familiares $y$ documentos administrativos (denominados colectivamente documentos vietnamitas). Se investigó sobre los nombres de lugares con elementos de origen Tay en la provincia de Tuyen Quang basándose en 4 distritos (Chiem Hoa, Lam Binh, Na Hang y Son Duong), con la intención de obtener ganancias sobre los nombres de lugares con elementos originales que provienen de las lenguas de las minorías étnicas en Vietnam que se leen y escriben de diferentes maneras. La diferencia en la fonética y la escritura de la lengua tay en comparación con el vietnamita, es una de las razones por las que los nombres de lugares con elementos de origen tay en la provincia de Tuyen Quang, se utilizan de manera inconsistente, lo que resulta en diferentes formas de leer y escribir un nombre de lugar. Por lo tanto, es necesario normalizar todos los topónimos situados en la provincia.

PALABRAS CLAVE: Nombres de lugares. Lengua tay. Fonética. Tuyen Quang. Vietnamita.

\section{Introduction}

Linguistics has many specializations, including Toponymy, which studies the origin, structure, semantics, variation, distribution and use of Toponymy. Toponymy explores different aspects of naming, and simultaneously learns about the language, culture of a region and a nation in general.

In the world, an overview of Toponymy research shows that research on the place name in the world with authors as Dauzat (1948), Rostaing (1965), Bright (2003), Comrie (2009), Cruse (2000) and Superanskaja (2002) etc. Studying about toponymy, we have found out that many authors claim that the name of a place is a unique title for each natural or unnatural subject in space.

According to Russian Linguistic Encyclopedia Dictionary, the study of place names (toponymy) is part of Onomastics (the study of titles) which studies the geographical names, the administration, and the transformation of those names over time (JATSEVA, 1990, p. $515)$.

According to Superanskaja (2002, p. 13), place names are words within the lexical resource of a language, denoted by individual words and subdivided into natural and artificial subtypes. They have common names and proper names. According to the author, a place, whether large or small, has a name which includes two parts: common name and proper name.

In Vietnam, there are many research approaches to Toponymy in Vietnam such as geographic-historical-cultural approach by authors: Nguyen Van Au (2003), Bui Thiet (1999), Nguyen Duoc and Trung Hai (2009), Nguyen Nhu Y (2011), etc.; linguistic approach by authors: Le Trung Hoa (2006; 1998), Nguyen Kien Truong (1996), Tu Thu Mai (2004), Phan 
Xuan Dam (2005), etc. However, the research on Toponym with original elements of ethnic minority languages in the northeastern region of our country is still limited, and no similar study has been conducted in Tuyen Quang province. Therefore, the article will be the first work to study the place names with the Tay original elements in Tuyen Quang province.

Tuyen Quang is a mountainous province in the Northeast of Vietnam. Tuyen Quang has more than 22 ethnic groups, in which Kinh, Tay, Dao, Cao Lan, Nung, Hoa, H ' Mong, San Diu are majority in population (ETHNIC MINORITIES COMMITTEE OF TUYEN QUANG PROVINCE, 1973). Tuyen Quang province is inhabited by many ethnic groups, in which the ethnic minorities account for $50 \%$ of the province's population. The study of place names in Tuyen Quang is focused on understanding the geographic names in the languages of different ethnic minority groups, in which Tay, Nung ethnic groups are the majority. The place names with original elements of the ethnic minority language are place names in Vietnamese, derived from the original language of the ethnic minority community in Tuyen Quang.

Ethnic minority languages in Tuyen Quang are mainly composed of the Tay - Nung group, belonging to the Tay - Thai language in the Thai - Kedai system; Hmong language in the Mèo branch, Dao in the Dao branch, both belonging to the Mèo - Dao system. Both are tonetic, isolating languages with their own phonetic, lexical, and spelling characteristics.

The research was conducted in four districts: Chiem Hoa, Lam Binh, Na Hang, and Son Duong, where most of the ethnic groups of the province are inhabited. The article mainly studies the place names with original elements of the Tay language because this is the language of the ethnic minorities, which occupy the largest population among ethnic communities of the province. In addition, only this language is used to name the ethnic minority places in socio-economic and cultural documents.

\section{Materials and methods}

\section{Some phonetic and writing characteristics of ethnic minority languages in Tuyen Quang province}

The scope of the article's research is to survey and study the topographical documents with elements of ethnic minority languages in Tuyen Quang province. In terms of geographical space, in Tuyen Quang province, ethnic minorities are concentrated mainly in Chiem Hoa, Lam Binh, Na Hang and Son Duong districts. Out of 1176 places collected in 3 districts, there are 1121 places of Tay origin, only 4 places of Hmong origin, 11 places of Dao 
origin. Therefore, the research scope of the article is limited to the Tay origin. The places outside the above scope, the Vietnamese famous places are temporarily not within the limit of our research material.

Fieldwork surveying and descriptive methods as well as interdisciplinary approach and some other methods have been utilized in the research. From there, the article obtained results on the original Tay places used uniformly/inconsistently, the meaning, the formation process, the change of the place names.

Ethnic minority languages in Tuyen Quang include many languages belonging to different language families. The languages of the ethnic groups in Tuyen Quang are classified into the following main groups: the Tay - Thai language group of the Tay, Cao Lan, and Nung ethnic groups; Mong and Dao language groups of the Mong, Dao, and Pa Then ethnic groups. We only learn about the famous places of Tay, belonging to the Tay - Thai language group, belonging to the Tai - Ka Dai language family. The Tay language is a branch of the Tai-Ka Dai language family - the largest language family in Southeast Asia. The Tai - Ka Dai language family includes 3 genera: Tay - Thai, Kam - Thuy, and Ka Dai. In the Tay - Thai genus, in Tuyen Quang province there are languages of the Tay, Nung, and Cao Lan people (HUU HOANH; VAN LOI; THONG, 2001, p. 32). The research object of this work is mainly the places of Tay origin. So, let's take a look at some characteristics of Tay phonetics.

\section{Results}

\section{In terms of Phonetic of Tay language}

According to Doan Thien Thuat (1996), the first consonant system of Tay language consists of 21 phonemes:

$\begin{array}{lclll}\mathrm{p} & \mathrm{t} & \mathrm{c} & \mathrm{k} & \text { ? } \\ \mathrm{ph} & \mathrm{th} & & \mathrm{kh} & \\ \mathrm{bd} & & & \\ \mathrm{m} & \mathrm{n} & \mathrm{nn} \mathrm{l} & \\ \mathrm{f} & \mathrm{s} & \mathrm{h} & \\ \mathrm{V} & \mathrm{z} & \\ \mathrm{l} & & \\ \mathrm{l} & & \\ + \text { Vowel: } & \end{array}$


Table 1 - The Tay vowel system consists of 9 basic vowels

\begin{tabular}{|l|c|c|c|}
\hline & Previous Line & Middle Line & Behind Line \\
\hline Close & $\mathrm{i}$ & $\mathrm{l}$ & $\mathrm{u}$ \\
\hline Medium & $\mathrm{e}$ & $\mathrm{r}$ & $\mathrm{o}$ \\
\hline Open & $\varepsilon$ & $\mathrm{a}$ & 0 \\
\hline
\end{tabular}

Source: Prepared by the authors

+ Last syllable :

The last syllable of Tay can be consonant or semi-vowel as follows:

Consonant: $\mathrm{p} \quad \mathrm{t} \quad \mathrm{k}$

$\mathrm{m} n \mathrm{n}$

Over vowel: $\mathrm{w} \mathrm{j} \quad$ u

+ Tones: According to Doan Thien Thuat (1996), the Tay language (Chinese dialect) has 5 tones: 1- the "horizontal" bar has a horizontal line (please denoted as bar 1); 2-bar "sharp" contours up (please denoted by bar 2); 3- bar "hyper" has a downward, low line (please denoted as bar 3); 4- bar "ask" has a down-up line (please denoted as bar 4); 5- bar "heavy" has a downward line (please denoted as bar 5).

\section{Writing of Tay language}

Regarding the origin and appearance of Nom Tay script, currently, among researchers, there is no consensus. According to the authors Nguyen Huu Hoanh, Nguyen Van Loi, Ta Van Thong (2001) and some other documents, most opinions believe that Tay nom script appeared in the sixteenth and seventeenth centuries.

Tay (Tay - Nung) Latin script is the second and most popular type of Tay script. Appearing from the period of resistance against the French, this type of script created by intellectuals based on Latin script was widely used in mobilizing the Tay people to join the resistance war and gain independence. In 1961, the State approved the Tay script. This is a Latin writing system that reflects quite accurately the phonetic features of the Tay language in the middle region, including areas such as Thach An, Trang Dinh, Bach Thong, etc. Tay script is built on the principle of using Quoc characters (a way to record the Tay language. Therefore, consonants, vowels, and tones with similar pronunciation to Vietnamese are recorded with symbols corresponding to Quoc Ngu characters.

In terms of writing, the first consonants in Tay language are as follows: 
Table 2 - The first consonants in Tay language are as follows

\begin{tabular}{|c|c|c|c|c|}
\hline No. & Phoneme & Symbol & Example & Meaning \\
\hline 1 & $/ \mathrm{b} /$ & $\mathrm{b}$ & buốc & swamp \\
\hline 2 & $/ \mathrm{k} /$ & $\mathrm{c}$ & co & \\
\hline & $/ \mathrm{k} /$ & $\mathrm{k}$ & kèn & sharp pain \\
\hline & $/ \mathrm{k} /$ & $\mathrm{q}$ & quéng & cocoon \\
\hline 3 & $|z|$ & d & dộc & basket \\
\hline 4 & $/ \mathrm{d} /$ & đ & đướt & hot, warm \\
\hline 5 & $/ \mathrm{f} /$ & $\mathrm{f}$ & fạ & Sky \\
\hline 6 & $/ \mathrm{h} /$ & $\mathrm{h}$ & hai & python \\
\hline 7 & $/ 1 /$ & 1 & lăng & back \\
\hline 8 & $/ \mathrm{m} /$ & $\mathrm{m}$ & mác & fruit \\
\hline 9 & $/ \mathrm{n} /$ & $\mathrm{n}$ & nà & field \\
\hline 10 & $/ \mathrm{r} /$ & $\mathrm{r}$ & rộc & bushy \\
\hline 11 & $/ \mathrm{p} /$ & $\mathrm{p}$ & pọ & handrails \\
\hline 12 & $/ \mathrm{s} /$ & $\mathrm{x}$ & $\mathrm{xu}$ & ear \\
\hline 13 & $/ t /$ & $\mathrm{t}$ & tu & door \\
\hline 14 & $/ \mathrm{v} /$ & $\mathrm{v}$ & vài & stride \\
\hline 15 & $/ \mathrm{n} /$ & $\mathrm{nh}$ & nháo & flock, group \\
\hline 16 & $/ \mathrm{n}$ & ng & ngà & sesame \\
\hline 17 & $/ \mathrm{c} /$ & ch & chí & jar \\
\hline 18 & /1/ & sl & slam & Three \\
\hline 19 & $/ \mathrm{ph} /$ & $\mathrm{ph}$ & phấy & bamboo \\
\hline 20 & /th/ & th & thát & sneeze \\
\hline 21 & $/ \mathrm{kh} /$ & $\mathrm{kh}$ & khủ & uncle \\
\hline 22 & $/ \mathrm{bj} /$ & $\mathrm{bj}$ & bjoóc & flower \\
\hline 23 & $/ \mathrm{pj} /$ & pj & pja & fish \\
\hline 25 & $/ \mathrm{phj} /$ & phj & phja & $\begin{array}{l}\text { limestone } \\
\text { mountain }\end{array}$ \\
\hline
\end{tabular}

Source: Prepared by the authors

In terms of writing, the vowels in Tay language are as follows:

Table 3 - The vowels in Tay language are as follow

\begin{tabular}{|c|c|c|c|c|}
\hline I & Phoneme & Symbol & Example & Meaning \\
\hline 1 & $\mathrm{a}$ & $\mathrm{a}$ & pa & grab \\
\hline 2 & $\breve{a}$ & $\check{a}$ & đăm & black \\
\hline 3 & $\gamma$ & o & lơ & chalk \\
\hline 4 & $\Phi \gamma^{2}$ & â & ngận & longan tree \\
\hline 5 & $\varepsilon$ & $\mathrm{e}$ & nèm & according to the \\
\hline 6 & $\mathrm{e}$ & $\hat{\mathrm{e}}$ & mên & foul \\
\hline 7 & $\mathrm{i}$ & i & tin & foot \\
\hline 8 & $\mathrm{u}$ & $\mathrm{u}$ & $\mathrm{mu}$ & pig \\
\hline 9 & u & ư & mử & auntie \\
\hline 1 & $\square \mathbf{0}$ & $\mathrm{o}$ & thói & remove \\
\hline 1 & o & ô & pồm & hot \\
\hline 1 & /ie/ & ie & riêc & call \\
\hline 2 & /ie/ & ja & mìa & wife \\
\hline 1 & /uo/ & uô & tuống & straps \\
\hline
\end{tabular}




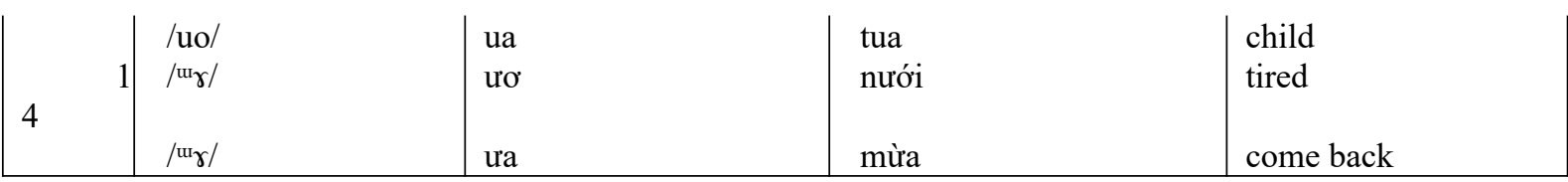

Source: Prepared by the authors

In terms of writing, thanh điệu:

With the 5 tones presented, the notation and recording of Tay tones are as follows:

1. crossbar

2. Sharp accent (')

3. The tilde ( ')
4. Question mark (?)

5. Heavy accent (.)

tilde dùng để ghi từ

mượn tiếng Việt: (ã)

\section{Phonetic comparison between Tay language and Vietnamese language}

- Tay language and Vietnamese are both syllabic and tonal languages. Syllables have a tight structure, consisting of some elements combined according to certain rules.

- The syllable is the morpheme shell.

- Vietnamese syllables as well as Tay syllables have a 2-level structure. Step 1: division of syllables into first, rhyme, and tone. Level 2: the division of rhymes into main and connecting sounds.

+ The first sound in both languages have consonants, including the throaty consonant / P/.

+ The main sound is played by single and diphthongs.

Tay, like Vietnamese, has 9 basic vowels, divided into three lines and three degrees of elevation. Regarding the line, there is a vowel contrast between the lines: before, between, after. In terms of openness, there are three levels of opposition: high, medium, and low.

In both languages there are 3 diphthongs: /ir/, /ur/, /wr/.

+ Last syllable: in both Tay and Vietnamese languages, there are ending consonants / $\mathrm{m} /, / \mathrm{n} /, / \mathrm{n} /$ and semi-vowels $/ \mathrm{j} /, / \mathrm{w} /$.

- Tone:

Regarding contours: both tonal systems in the two languages have opposites by the criteria of opposing lines: horizontal bars, down bars, up bars, and up bars.

In terms of pitch, both tonal systems in the two languages have contrasting highs and lows. 


\section{Phonetic difference}

+ First consonant:

In Tay language there are consonants $/ \mathrm{bj} /, / \mathrm{mj} /, / \mathrm{pj} /, / \mathrm{phj} /$.

In the Tay language, there is a contrast between the consonant rubbing - lip tooth /f/ with the consonant lip - lip /ph/. In Vietnamese, there is no lip-lip consonant/ph/.

In the Tay language, there is a side rubbing consonant / $1 /$. In Vietnamese, there is no.

Vietnamese has consonants $/ \chi /, / \mathrm{V} /$. In the Tay language, the consonant stop $/ \mathrm{kh} /$.

+ Vowels:

In the Tay language, there is a contrast between short vowels and long vowels, especially the contrast between the two vowels $/ 0 /$ and $/ \varepsilon /$. In Vietnamese, there is no.

\section{Comparison of writing between Tay and Vietnamese}

Basically, the use of characters and writing rules of the Tay language is similar to the National language. The scripts of both languages use Latin characters to represent consonants and vowels. All tones are marked with diacritics. The symbols for consonants and vowels are essentially the same.

Tonality recording in both languages use "horizontal", "hypher", "ask", "sharp", "heavy" to record the tones. In the Tay language, there are similar features of contours and tones as in Vietnamese.

+ About consonant characters:

In the Tay language, the character "ph" is used to record a closed-lip consonant - a slightly raised lip /ph/. Meanwhile, Vietnamese uses "ph" to record the consonant /f/.

In Tay language, there are characters to record consonant sounds $/ \mathrm{bj} /, / \mathrm{mj} /, / \mathrm{pj} /, / \mathrm{phj} /$ as with the letter "i". In Vietnamese, there are neither surprise phonemes nor characters to record these sounds.

In the Tay language, there is the character "sl" to record the consonant $/ 1 /$. In Vietnamese, there is no.

+ About vowel characters:

In the Tay language, there are long vowels recorded with two consecutive letters (eg "oo"). In Vietnamese, there is no. 
+ About tone:

In the Tay language, there is no tilde, so tilde is not used in writing.

The difference in phonetic and scripting of Tay language compared to Vietnamese is one of the reasons that make place names with Tay-origin elements in Tuyen Quang province being used inconsistently, which results in different ways of reading and writing the name of a place; therefore, there is a need to standardize all the names of places.

\section{The current situation of place names with elements of Tay origin in Tuyen Quang}

In the place names that have the original Tay element in Tuyen Quang, besides the places that are used consistently, there is also a part that has not been unified, that is, the same place name but has different spellings and readings in Quoc language. The specific results are as follows:

Out of a total of 1176 places with elements of Tay origin, 794 places are used uniformly in survey documents and maps (accounting for 67.52\%), in which, the highest concentration is in the text area. Vietnamese language with 458 place names, accounting for $38.95 \%$ of the total number of place names (Vietnamese documents such as: List of population, mountain name, water name; Documentation on civil status, household registration and a number of administrative documents other). Thus, in Vietnamese documents, place names with ethnic elements are used quite uniformly. The rest are places that are used inconsistently.

\section{Unified use of place names}

On the basis of analysis, comparison and comparison of research documents on place names with elements of Tay origin in Tuyen Quang, the number of consistently used place names is quite large with 794 places, accounting for $6752 \%$. The specific results for each type of location are as follows: 
Table 4 - Location Names of uniform use

\begin{tabular}{|l|l|l|l|}
\hline No & Type of place name & Quantity & Ratio (\%) \\
\hline 1 & Natural terrain & 389 & 49,0 \\
\hline 2 & Residential unit & 176 & 22,16 \\
\hline 3 & Man-made construction & 229 & 28,84 \\
\hline & Total & 794 & 100 \\
\hline
\end{tabular}

Source: Prepared by the authors

Looking at the above research results, it shows that, among the types of place names, the one that is used uniformly with the largest number is the group of natural topographic landmarks with 389 places, accounting for $49.0 \%$. The group of place names of residential units has the least number of places used consistently in the three types with 176 place names, accounting for $22.16 \%$. The group of man-made landmarks ranked second with 229 landmarks, accounting for $28.84 \%$.

The geographical units of nature mainly exist in people's daily communication, the representation on national maps and local administrative maps is very little. The results of surveying the data of this group of landmarks by field method are mainly, some landmarks are collected from local press documents, therefore, the results of research on the use of place names are consistent. in this group of landmarks is quite large.

The group of places of artificial works is collected from maps of all kinds and Vietnamese documents, so there has been a certain treatment. In particular, the group of manmade landmarks has had the intervention of government agencies from the central to local levels in decisions on construction planning, so the number of landmarks used uniformly is pretty big.

From the above results, it can be seen that the group of geographical units of natural units are rarely included in maps and Vietnamese documents, rarely appear in legal documents, that is, they mainly exist only in the calling of Vietnamese people. People rarely call different names for the same place. In contrast, the group of geographical names of residential units are mainly collected from the list of administrative units at all levels of the local government, the historical and cultural documents of the locality, that is, appear in many documents. Vietnamese versions in many documents, at different times, have the lowest degree of consistency. Due to the influence of the "Vietnamization" of places with ethnic elements in different ways, a large part of these places are written in different ways. 


\section{Locations used inconsistently}

Due to many different reasons, there are many places with the original element of ethnic minority language with different spellings in the national language script. The article surveyed 382 cases, in which, in different types of place names and different locations, the level of inconsistent use of place names is not the same. The specific results are as follows:

In Chiem Hoa district, there is the largest difference with 188 cases (accounting for $49.21 \%$ of the total number of cases of using inconsistent place names), in which the geographical location of the residential unit is the main with 143 cases, natural topographical landmarks are 42 cases, artificial construction sites are 3 cases.

$\mathrm{Na}$ Hang district has 99 cases (accounting for $25.92 \%$ of the total number of nonuniform use of place names), of which residential place names are 73 cases, natural topographic landmarks are 22 cases, and geographical locations are geographical. The list of artificial works is 4 cases. Lam Binh district has 66 cases (accounting for $17.28 \%$ of the total number of inconsistent landmarks), in which the population unit is 41 cases of natural topographic landmarks 19 cases, artificial construction sites are 6 cases. Son Duong district with 29 cases (accounting for 7.59\%), there are 26 landmarks of residential units and 9 places of natural topography, 4 cases of artificial construction sites.

From the above results, it can be seen that the high mountain districts of Tuyen Quang province are directly proportional to the degree of inconsistency in the spelling of place names. Son Duong district has less difference than other districts due to the historical cultural characteristics of the district. Son Duong is a district with many lowland people, many revolutionary cadres came here to live and work during the Revolution and Resistance period. Therefore, place names are less misleading than other localities.

The reasons for the inconsistent use of place names with elements of Tay origin in Tuyen Quang province

As is known, "Location is a word like other words, subject to the influence of phonetic laws" [56; 109]. In that impact, local phonetics is one of the important causes leading to the change in the reading of place names. It is the phonetic differences between the Tay and 
Vietnamese languages that are one of the reasons why the same place has different spellings and readings. Below are the specific presentations.

\section{Due to transliteration}

When Vietnamese becomes the national language, when the names of ethnic minorities are recorded according to the Vietnamese way of calling them, the place names with the original elements of the ethnic language are officially written in the Vietnamese script to facilitate communication. Through many times of standardizing place names, many places have changed. However, there are certain differences between the Quoc Ngu script and the way it is called in the ethnic minority language. In some cases, the Quoc Ngu script cannot accurately reflect the calling sound, making it difficult to record the pronunciation of the ethnic minorities, so some place names with elements of ethnic minorities have been popularized for easy reading according to the Mandarin sound pattern. Therefore, there are some places with a certain negative bias.

In the past, Tuyen Quang's mountainous region was a fairly concentrated residence of the Tay, Nung, Dao, and Mong indigenous ethnic groups. However, the area of residence of the people did not have a clear distinction but lived alternately. together. The lives of ethnic minorities in general have not changed much before historical fluctuations like in the lowlands. But not because of that, the ethnic minorities in Tuyen Quang do not have exchanges and have a certain impact on the formation and change of their place names. They have a way of naming and naming places in their mother tongue, but they are also greatly affected when they interact with the Kinh people. That almost fixed life was changed to a certain extent when they came into contact with Kinh groups. This happens two possibilities. Firstly, besides the place names called in their own language, the ethnic minorities in Tuyen Quang have an impact in their exchange relations with the Kinh people, especially when the Kinh live interspersed with other ethnic minorities. Some people have left traces of their language (for example, the elements "village", "village"). The ethnic minorities heard the Kinh call it and then called it, so there was the word village, next to their villages. ethnic minorities. Thus, in the very way of calling the place names of the Tuyen Quang ethnic minority people, there are certain imprints of the exchange between the local language and the Vietnamese language.

In contrast, Kinh people living with ethnic minorities face many difficulties when pronouncing places according to the local language. Therefore, many places are called with 
Kinh sounds similar to Tay to call them. When the Tay had a script, they wrote the places according to their pronunciation. The Kinh people have their own ways of writing and reading according to their language habits. That makes each group of people register a different place. This is one of the reasons why the same place name has many different names.

Due to different geographical locations, in the high mountains, the difference between places is higher than in the lowlands. Specifically, in the four studied districts, Son Duong district has the least difference in place names. With its geographical position adjacent to Thai Nguyen, Phu Tho, and Vinh Phuc provinces, the ethnic minorities in Son Duong district soon had economic and cultural exchanges with neighboring provinces and with neighboring plains provinces.

In addition to a number of geographical elements that are Vietnameseized, the elements of place names with elements of ethnic minority origin are also relatively standardized. On the other hand, it is this contact and exchange that also causes the remaining places with ethnic elements to be affected according to "King Hoa".

In the place name "Na Lang", the element "glossy" has been Vietnameseized. This is a famous place of Tay, read and written in Tay language as: "loong" means "to hide" (this is a dense forest, easy to enter and hide). Also because of this nature, the forest named "Na Loong" was chosen by the Communist Party of Vietnam and Uncle Ho as the venue for the second National Congress of the Party (February 1951). During the contact between Vietnamese and Kinh, this place was Vietnameseized into "Na Lang". The "glossy" element, though easy to read in both Tay and Vietnamese, becomes meaningless. However, the language community still accepts "nonsense" and still calls the place "Na Lang" due to the habit of using the language.

\section{Borrowing sound}

Some places have elements of ethnic minorities that make it difficult for Vietnamese people to pronounce. Therefore, sound borrowing is done to refer to a word with Vietnamese phonetics that sounds similar to a place name with an ethnic minority element to name that place. For example, Ga pass (gateway of Vinh Loc town, Chiem Hoa district). The original sound of Ga pass is pull Kha (a pass with many grasses), the Kinh people borrowed the Vietnamese sound of Ga pass, which sounds similar to drag Kha to call this place. The place name of Ban Pai village (village, hamlet, roof) (Minh Quang commune, h.CH) is called Bai village with borrowed sound. 
The place name of Co Yeng pass $(\mathrm{NH})$ was originally named Khuoi Dieng, which means "well spring", however, through the process of contact with Tay - Vietnamese language, the original element was lost, making people think that this is not must be the original place name of the ethnic minority people, but the common language when determining the place name means the part that is the "neck" of the Yeng bird. There are the following explanations:

First, according to legend, the place Co Yeng pass is the end of a love story about the love of two students and the daughter of a teacher. When the girl's father died, the girl didn't know who to choose as her husband, so she asked the bird. The bird called out Nam's name. The girl chose Nam as her husband, lived together, and gave birth to a son. 3 years later, Nam went to work far away and was nowhere to be found. Nam's wife thought that her husband was dead, so she married Phai. Ten years later, Nam returned, pretending to be a merchant, returned to find that the scene had changed. Nam wants to give some money to his wife and children, so he asks to buy Yeng's child at a high price. Nam Nam carried Yeng up the hill and disappeared. This place is now called the hill "with Yeng", and it is called Co Yeng. Thus, if explained in this way, the place name of Co Yeng pass has the original element of Kinh language.

Second, Co Yeng Pass makes people deduce that the reason for the place name is because the shape of the pass is winding like the neck of the bird Yeng. This is similar to case 1.

Thirdly, Co Yeng Pass, the original name is Khuoi Yeng in Tay language, which translates into Vietnamese as "well stream". According to the actual characteristics of the place, from the top of the pass, looking down at the stream, gliding down to the foot of the mountain, creating an abyss like a giant well without seeing the bottom. In the Tay language, the bird can be read as "Diang". And the Kinh people confused "Yeng" with "Diang", misread "Koi Yeng" into "Co Yeng" as it is today. In the present, indigenous people still call Khuoi Yeng as the only place to pass before entering Na Hang district capital. For example, "The last pistil of Keo Yeng/Thong is the Na Hang electric rainstorm... (The forest banana flower flickers on Khuoi Yeng pass/ Soi walks us to a bright area in Na Hang).

\section{Conclusion}

Place names originated in ethnic minority languages in Tuyen Quang province can also reflect the exchange of language culture with other groups of people in the region. That is reflected in the borrowing or the influence of languages in the nomination. Place names 
originated in ethnic minority languages are recognized through language layers of the native ethnic minority people, other ethnic minorities, Kinh people. Place names originated in ethnic minority languages are subjected to this interaction, which can be popularized by Kinh language (partially or completely) in terms of phonetics or semantics. It is the very contact that causes many place names to be inconsistent. The cause of the phenomenon of place names with elements of Tay origin in Tuyen Quang province is not consistent, mainly due to the phonetic characteristics of the Tay language, which have certain differences with Vietnamese, as well as the writing system. the difference should lead to misreading, wrong writing. Overcoming these causes is the job of making the places with the original Tay language in Tuyen Quang province convenient for practical use.

Practical implications: Dinh Tran Ngoc Huy, Nguyen Thi Thuy Hanh, Nguyen Thi Hang et al (2021) also mentioned updating knowledge for enhancing teachers' capabilities in educational schools an environment.

ACKNOWLEDGEMENTS: This research is funded by Tan Trao University in Tuyen Quang, Viet Nam. Thank you, Tan Trao University, editors, friends, and brothers, to support this publication.

\section{REFERENCES}

COMRIE, B. The word's major langguage. 2. ed. London, New York: Routledge, 2009.

CRUSE. D. A. Meaning in language: an introduction to semantics and pragmtics. Oxford University Press, 2000.

DAUZAT. A. La Toponnymie frangcaise. Paris, 1948.

DUOC, N.; HAI, T. Handbook of vietnamese places. Vietnam Education Publishing House, 2009.

DUONG THI TINH, D. et al. doing business research and teaching methodology for undergraduate, postgraduate and doctoral students-case in various markets including vietnam. Elementary Education Online, v. 20, n. 1, p. 1414-1418, 2021.

\section{ETHNIC MINORITIES COMMITTEE OF TUYEN QUANG PROVINCE. Ethnic} Minorities in Tuyen Quang. 1973.

FELLMANN, J. D.; GETIS, A. G. V. J. Human geography: landscapes of human activities. NXB Surendra Kumar tái bản lần thứ 5, p. 154-155, 1998. 
HOA, L. T. Basic principles in the study of place names. Social Science Publishing House, 1998.

HOA, L. T. Vietnam topography. Social Science Publishing House, 2006.

HUY, D. T. N. The Critical Analysis of Limited South Asian Corporate Governance Standards After Financial Crisis, International Journal for Quality Research, v. 9, n. 4, p. 741-764, 2015.

NGUYEN VAN, L. Language and writing of ethnic minorities in vietnam. Hanoi: Encyclopedia Publishing House, 2003.

THI HOA, N. et al. Human resource for schools of politics and for international relation during globalization and EVFTA. Elementary education online, v. 20, n. 4, p. 2276-2288, 2021 .

THIEN THUAT, D. Tay nung language in the north vietnam. Tokyo Univ of Foreign Studies Press, 1996.

THIEN THUAT, D. Vietnamese Phonetics. Hanoi National University Publishing House, 2016.

THIET, B. Cultural landmarks of Vietnam. Hanoi: Youth Publishing House, 1999.

TRAN NGOC HUY, D. et al. General solutions for enhancing quality of teachers during globalization in emerging markets including vietnam-and some pedagogy psychological issues. Psychology and Education, v. 58, n. 4, p. 2343-2349, 2021.

TRAN NGOC HUY, D.; THU THUY, N. Education for students to enhance research skills and meet demand from workplace-case in vietnam. Elementary Education Online, v. 20, n. 4, p. 606-611, 2021.

\section{How to reference this article}

THI NGU, D; TRAN NGOC HUY, D. Ethnic minority language culture, places with original tay language elements and names inconsistence in Tuyen Quang provinces. Rev. EntreLínguas, Araraquara, v. 7, n. 00, e021039, 2021. e-ISSN: 2447-3529. DOI: https://doi.org/10.29051/el.v7i1.15673 
Submitted: $10 / 08 / 2021$

Required revisions: $25 / 08 / 2021$

Approved: $12 / 09 / 2021$

Published: 08/10/2021 